\title{
Mencapai Sustainability Koperasi Pesantren melalui Jiwa Entrepreneurship pada Mahasantri Lembaga Tinggi Pesantren Luhur Malang
}

\author{
Nihayatu Aslamatis Solekah \\ Fakultas Ekonomi \\ UIN Maulana Malik Ibrahim, Malang \\ E-Mail: aslamatiss_1@pbs.uin-malang.ac.id

\section{Barianto Nurasri Sudarmawan \\ Fakultas Ekonomi \\ UIN Maulana Malik Ibrahim, Malang \\ E-Mail: barianto@uin-malang.ac.id}

\author{
Titis Miranti \\ Fakultas Ekonomi \\ UIN Maulana Malik Ibrahim, Malang \\ E-Mail: titis@uin-malang.ac.id
}

\section{Article History:}

Received: 2019-12-04

Revised: 2020-01-17

Accepted: 2020-05-31
Keywords: Cooperative

Management, Enterpreneurship,

Pesantren Cooperatives,

Participatory Action Research

(PAR)

\begin{abstract}
Entrepreneurial activities within the pesantren are increasingly prevalent. This condition makes the ministry of industry participates in developing cooperatives through Islamic boarding schools throughout the nation. The Lembaga Tinggi Pesantren Luhur Malang not only focuses on teaching religious practices such as recitation, halaqoh, and prayer in congregation, but also giving students understanding and education in the economic field. This community service aimed at providing assistance in the form of cooperative management through the spirit of entrepreneurship of the students of Malang Luhur Pesantren. Participatory Action Research (PAR) was employed. The program resulted in a finding that there were a lot of ideas about entrepreneurship, even among those who had carried out these activities. However, the management needed improvement. The service team recommended the need to continuously increase the student resources who are able to market the results of pesantren cooperatives, and the need for support as well as supervision among each LTPLM member.
\end{abstract}

\section{Pendahuluan}

Peran entrepreneur dalam suatu negara adalah sebagai (1) Pemutar gerak roda ekonomi; (2) Pembuka atau penyedia lapangan kerja; (3) Pembayar pajak sebagai sumber pemasukan APBN/APBD; (4) Penghasil devisa dari produk ekspor yang akan memperkuat cadangan devisa negara; (5) Pelaku fungsi social dalam memajukan bangsa melalui sumbangan-sumbangannya di berbagai bidang seperti pendidikan, budaya, kesehatan, agama kemanusiaan, dan sebagainya; (6) Pendorong tumbuhnya 
entrepreneur-entreprenur baru. ${ }^{1}$

Oleh karena itu, pengembangan terhadap entrepreneurship menjadi agenda yang sangat penting dalam perjalanannya. Jiwa wirausaha (entrepreneurship) terbukti mampu menggerakkan perekonomian masyarakat dan sekaligus menjadi sumber pendapatan utama bagi mereka sebagai upaya peningkatan kesejahteraannya ${ }^{2}$. Dikarenakan dinilai efektif menggerakkan ekonomi kerakyatan, kementerian perindustrian pun kini ikut mengembangkan koperasi lewat pesantren-pesantren di seluruh Nusantara. Sebagai gambaran singkat berikut gambaran koperasi aktif di Indonesia.

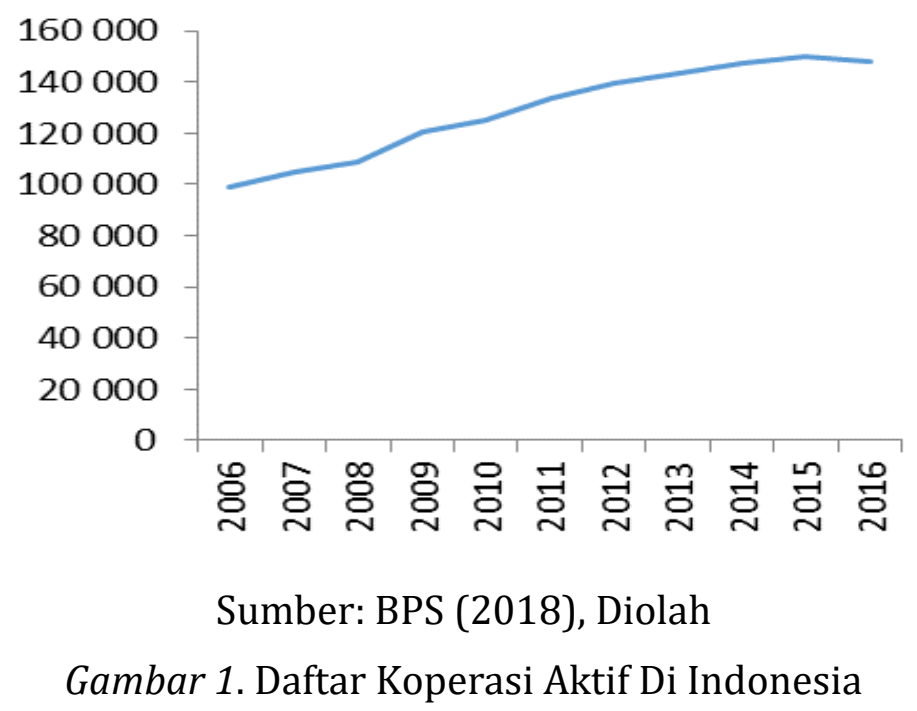

Berdasarkan data di atas, jumlah koperasi aktif di Indonesia mengalami peningkatan dalam 10 tahun terakhir. Pada tahun 2006, Jumlah koperasi di Indonesia sebesar 98.944. Sedangkan pada tahun 2016, terjadi peningkatan sebesar 148.220. Sementara itu, diperkirakan, terdapat sekitar 28 ribu pondok pesantren yang tersebar dari Sabang sampai Merauke.

Pemilihan pengembangan di wilayah pesantren juga bukan tanpa sebab, pesantren dinilai memiliki potensi yang sangat melimpah ${ }^{3}$. Pengembangan koperasi lewat pesantren bisa ikut mendukung peran koperasi untuk menjadi kekuatan baru yang bisa mengakselarasi peningkatan daya saing industri dalam negeri. Ini khususnya untuk pengembangan sektor industri kecil dan menengah (IKM).

Dalam perkembangannya, banyak koperasi pesantren yang ditemukan dalam 1988).

${ }^{1}$ Deliar Noer, Perubahan, Pembaruan, Dan Kesadaran Menghadapi Abad Ke-21 (Dian Rakyat,

2 Wiwik Maryati, "Peran Perguruan Tinggi Dalam Pemberdayaan Entrepreneurship Untuk Mengembangkan Wirausahawan Kecil Menghadapi Persaingan Global," Prosiding Seminas 1, no. 2 (2012).

3 Toha Ma'sum and Muh Barid Nizarudin Wajdi, "Pengembangan Kemandirian Pesantren Melalui Program Santripreneur," ENGAGEMENT 2, no. 2 (2018): 221-232. 
keadaan non aktif. Hal ini memiliki arti bahwa tingkat partisipasi anggota masih tergolong rendah ${ }^{4}$. Pada temuan yang lain diketahui bahwa, kurang dari $2 \%$ pesantren yang mendirikan koperasi. Selain itu, minimnya keterlibatan warga pesantren yang menjadi anggota, sehingga angka partisipasi anggota pun menjadi rendah. Temuan lainnya adalah masih rendahnya motivasi berkoperasi dari warga pesantren yang berorientasi pada pengembangan kultur budaya pondok pesantren ${ }^{5}$.

Pesantren Luhur Malang merupakan salah satu pesantren yang ada di kota Malang, tepatnya di kelurahan Ketawanggede Kecamatan Lowokwaru. Pesantren ini didirikan untuk mewadahi para mahasiswa yang berminat untuk menjadi santri, dikarenakan lokasi pesantren ini yang sangat strategis ditengah-tengah beberapa universitas di kota Malang.

Nama Pesatren Luhur bukanlah nama yang diberikan oleh para pendiri Pesantren Luhur yang ada di Malang, melaikan sudah sejak dari dulu, yang dilahirkan oleh organisasi Islam se-Indonesia tersebut. Dokumentasi tentang keputusan rencana mendirikan pesatren Luhur di berbagai kota besar diberikan oleh Prof. Dr. Kyai H. Achmad Mudlor, SH. kepada Prof. Dr. Mr. H. Moh. Khoesnoe yang untuk selanjutnya di sampaikan kepada Sekjen Depag yaitu Bapak H. Moh. Anshor (Mertua Prof. Khoesnoe). Pada waktu itu menteri agama dijabat oleh Kyai H. Syaifuddin Zuhri. Karena beliau tertarik dengan gagasan tersebut, maka dikalangan Depag dibentuk Dirjen Pesantren Luhur dan Perguruan Tinggi. Untuk merespon program Depag tersebut, maka di Malang pada awal tahun 1960 didirikan Pesantren Luhur oleh tokoh-tokoh Islam Malang antara lain Kyai H. Ghozali, Prof. Dr. Mr. H. Mohammad Koesnoe, Kyai H. Usman Mansyur dan Prof. Kyai H. Achmad Mudlor, SH. Ciri-ciri pokok Pesantren Luhur tersebut diantaranya adalah memperdalam kitab-kitab salafiyah namun berkiprah sebagaimana perguruan tinggi, khusunya dalam merealisir Tri Darma Perguruan Tinggi.

Pesantren Luhur Malang berada di jalan raya Sumbersari no 88 Malang dengan kondisi yang strategis. Hal tersebut sangat mendukung aktivitas santri yang merupakan mahasiswa dari berbagai universitas di Malang (UB, UM, UMM, UIN Maliki, POLTEKES, POLINEMA dan STIH). Keragaman ini meningkatkan solidaritas dan triple Co. (Co ownership, Co determination, Co responsibility) merupakan semboyan santri yang sering didengungkan oleh pengasuh LTPLM. Secara fisik Pesantren Luhur Malang terdiri atas empat lantai serta terdpat tiga menara kembar yang menjulang tinggi diatasnya. Kompleks putri menempati 4 lantai yang terbagi dalam beberapa blok (Blok Mbak Daris, A, B, C, D, E, F dan Gedung Azka, sedangkan untuk kompleks putra menempati 3

4 Gunawan Aji, "Faktor-Faktor Yang Mempengaruhi Kinerja Koperasi Pondok Pesantren," Walisongo: Jurnal Penelitian Sosial Keagamaan 19, no. 1 (2011): 231-260.

${ }^{5}$ Hasyim, Analisis Peranan Partisipasi Santri Terhadap Perkembangan Koperasi Pondok Pesantren Di Kota Semarang (Semarang, 2008). Lihat juga Aji, "Faktor-Faktor Yang Mempengaruhi Kinerja Koperasi Pondok Pesantren." Hasyim Syarbani, "Analisis Pengaruh Partisipasi Santri Komitmen Dan Kemampuan Berinovasi Terhadap Kinerja Koperasi Pondok Pesantren Di Kota Semarang," Economica: Jurnal Ekonomi Islam 2, no. 2 (2012): 27-42. 
lantai yang terbagi dalam tiga blok (A, B dan C). Pesantren Luhur memiliki beberapa fasilitas lainnya seperti Masjid sebagai temapat berbagai aktivitas, seperti sholat berjamaah, pengajian, maupun musyawarah serta dilengkapi dengan tiga aula luas yang berada di lantai dua (bersebelahan dengan masjid), di lantai satu (diantara kompleks putra) dan di lantai tiga (kompleks putri).

Jumlah santri yang mendiami Pesantren Luhur pada bulan Juli 2019 berjumlah 280 orang. Dengan rincian 190 putri dan 90 putra. Dari tahun ke tahun jumlah santri terus bertambah, seingga pengasuh selalu mengadakan pembangunan dan renovasi agar pesantren dapat berkembang dan memfasilitasi santri-santrinya dengan baik. Di komplek putri tersedia kamar mandi yang jumlahnya cukup banyak, untuk putri terdapat 18 kamar mandi, sedangkan untuk santri putra terdapat 8 kamar mandi.

Berdasarkan hasil pengamatan lapang, model pengelolaan pada koperasi ini memiliki sedikit perbedaan dengan beberapa pesantren pada umumnya. Pendiri pesantren Luhur Malang Prof. Dr. Kyai H Achmad Muhdlor SH sejak awal memberikan porsi yang besar untuk para santri dalam ikut berperan mengembangkan pesantren tersebut. Selain pendidikan keagamaan berupa pengajian, halaqoh, sholat berjamaah, pondok pesantren ini juga berfokus memberikan para santri pemahaman dan pendidikan di bidang ekonomi. Sebuah pendidikan yang memiliki tujuan agar para santri diharapkan bisa mengelola semua kebutuhan pesantren dengan sendirinya.

Kemandirian menjadi poin penting dari pendidikan bidang ekonomi ini. Hal ini menjadi perlu dilakukan karena semua operasional pesantren dikelola oleh santri sendiri. Berdasarkan hasil observasi partisipatif dan wawancara dahulu koperasi ini pernah memiliki beberapa bentuk usaha yang menjadi buah pendidikan ekonomi, adapun usaha itu yakni wartel (warung telekomunikasi), rental komputer, serta mini koperasi yang menyediakan kebutuhan para santri. Pesantren Luhur Malang dilengkapi dengan koperasi, kantin dan warnet yang disebut dengan Luhur Net sebagai sumber ekonomi yang dapat diatur sirkulasinya oleh santri.

Namun demikian, permasalahan yang seringkali muncul adalah lemahnya aspek manajerial dalam pengelolaan koperasi pesantren tersebut. Sehingga diperlukan penguatan dan pendampingan merubah mindset para Mahasantri Lembaga Tinggi Pesantren Luhur untuk mengelola potensi koperasi tersebut dengan baik.

Berdasarkan fenomena di atas, maka perlu dilakukan penelitian action research dalam rangka penguatan entrepreneural koperasi pesantren guna meningkatkan nilai ekonomi pesantren sebagai tanggung jawab moral perguruan tinggi dalam rangka pengabdian dan pembenahan masyarakat pesantren.

Dari obeservasi awal di lingkungan pesantrean masih terdapat beberapa potensi yang dapat diberdayakan guna meningkatkan dari aspek sosial, ekonomi dan lingkungannya: (1) Kondisi koperasi pesantren yang memerlukan penguatan aspek manajerial sehingga koperasi pesantren tersebut dapat dikelola dengan baik; (2) 
Pendampingan kreatifitas mahasantri dalam menambahkan ide-ide baru guna meningkatkan nilai ekonomi dan menciptakan lingkungan pesantren dinamis dan kreatif; (3) Perlunya sumberdaya santri yang mampu memasarkan hasil koperasi pesantren yang dapat meningkatkan nilaiguna ekonomi seperti untuk catering atau even-even tertentu; (4) Perlunya peningkatan skill sumberdaya santri yatim dalam melaporkan keuangan koperasi pesantren mengingat koperasi pesantren ini masih belum memiliki laporan keuangan yang terstandarisasi; (4) Aspek sosial dan pembelajaran kemandirian pada mahasantri dapat diwujudkan melalui penguatan pengelolaan koperasi dan kantin dalam menumbuhkan jiwa wirausaha (enterpreneur).

\section{Metode}

Metode action research ini digunakan untuk tidak membuat masyarakat (santri) dampingan sebagai obyek, tetapi menjadikannya sebagai subyek penelitian. Masyarakat santri sendiri yang memahami, menginginkan, dan memecahkan permasalahan yang melilitnya. Posisi peneliti lebih sebagai fasilitator bagi mahasantri untuk mencapai citacitanya dan memberikan jalan keluar dan merumuskan strategi yang dapat digunakan mereka ntuk mencari jalan keluar bagi permasalahan mereka. Namun perumusan jalan keluar dan strategi ini tetap melibatkan mahasantri dengan harapan apabila mahasantri mengalami masalah-masalah apa saja sosial, ekonomi dan lingkungan atau lainnya mereka bisa memecahkan permasalahan mereka sendiri tanpa bantuan orang lain.

Dengan Participatory Action Research (PAR) ini bermanfaat untuk memfasilitasi dan memotivasi supaya: (1) mereka mampu mengidentifikasi potensi, kekuatan dan kelemahan yang ada pada lingkungan pesantren dan/atau lingkungan masyarakat secara umum; (2) mereka mampu menemukenali apa yang harus dilakukan setelah point satu di atas dapat terekam; (3) menyusun strategi dan metode yang tepat untuk memecahkan problematiknya; dan (4) menyusun rencana aksi berdasarkan prioritas, dan keberlanjutan program melalui tahapan-tahapan hingga mencapai target yang diharapkan

Prioritas program ini adalah penguatan entrepreneurial mahasantri dalam mengelola koperasi pesantren utamanya penguatan softskill sumberdaya mahasantri serta meningkatkan kreatifitas mahasantri dalam mengelola koperasi pesantrean tersebut berdasarkan hasil observasi awal pada awal bulan tahun 2019. Dari gambaran proses penelitian action research ini ada beberapa tahapan sebagai berikut: (1) Perencanaan (plan). Perencanaan ini dilakukan setelah memperhatikan kondisi riil di Lembaga Tinggi Pesantren Luhur Malang menggunakan analisis SWOT dimana pada tahap ini adalah merencanakan bagaimana merubah perilaku dan mindset entrepreneural mahasantri dalam memanfaatkan koperasi pesantren yang telah ada; (2) Tindakan (action). Setelah proses perencanaan dilakukan, mengimplementasikan rencana yang telah dibuat tersebut dengan dibantu dan difasilitatori oleh peneliti. 
Tindakan yang akan dilakukan adalah berupa pelatihan penguatan soft skill sumberdaya mahasantri dan meningkatkan kreatifitas dan mindset mahasantri agar bisa menggali potensi dan peluang-peluang baru yang bisa digunakan untuk mengembangkan koperasi pesantren. Selain itu, penguatan entrepreneural mahasantri dalam mengelola koperasi pesantren serta pendampingan soft skill sumberdaya mahasantri, manajemen pemasaran berbasis teknologi serta manajemen keuangan koperasi pesantren yang transparan dan akuntabel; (3) Refleksi (reflect). Usaha-usaha yang telah dilakukan dalam memecahkan problematika di direfleksikan dan dievaluasi, baik kekurangan, kelemahan, dan keberhasilan strategi dan metode dalam memecahkan problematika mahasantri tersebut.

Dalam rangka mengubah kondisi mahasantri Pesantren Luhur Malang baik secara sosial, ekonomi dan lingkungan, digunakan metode PAR (Participatory Action Research). Metode ini dilakukan untuk memahamkan masyarakat santri terhadap: (1) potensi-potensi yang dimiliki di lingkungan pesantren seperti memanfaatkan koperasi dan kantin pesantren yang telah berjalan semaksimal mungkin; dan (2) keinginankeinginan masyarakat santri untuk mengatasi kekurangan dan kelemahannya khususnya berkaitan dengan penguatan mental entrepreneurial dalam pengelolaan koperasi pesantren.

Pada tahap ini, dalam proses pemberdayaan mahasantri biasa juga disebut dengan community strategic planning. Community Strategic Planning merupakan suatu proses mengorganisir gagasan-gagasan yang muncul dalam mencari peluang-peluang yang mungkin bisa dilakukan bersama guna memecahkan masalah.

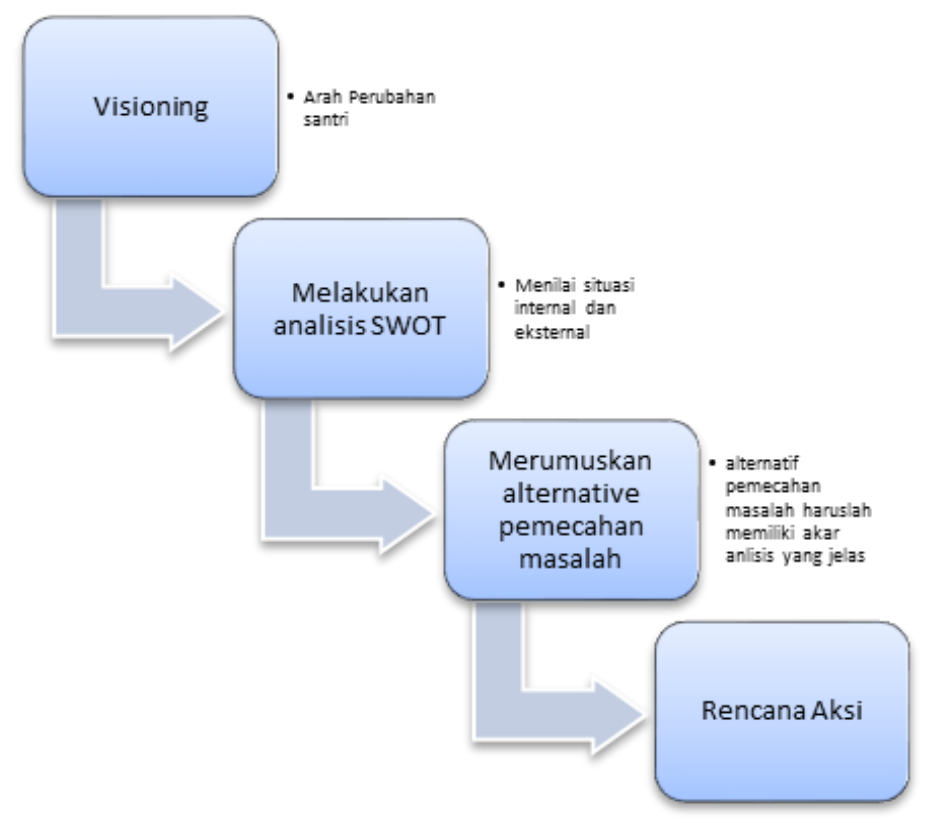

Gambar 2. Langkah-langkah strategi utama ${ }^{6}$

${ }^{6}$ Masykuri Bakri, Pemberdayaan Masyarakat Pendekatan RRA Dan PRA (Surabaya: Visipress 
Kegiatan ini diawali dengan mengidentifikasi potensi yang dimiliki Pesantren Luhur Malang. Setelah mengidentifikasi beberapa potensi yang dimiliki oleh Lembaga Tinggi serta beberapa permasalahan yang mereka hadapi didalam menguatkan potensi entrepreneurial koperasi pesantren maka program yang kita rencanakan adalah khusus pada penguatan skill entrepreneurial mahasantri dalam mengelola koperasi pesantren dan penguatan skill mahasantri dalam meningkatkan ide-ide kreatif serta memasarkan produk-produk yang mereka buat.

\section{Hasil dan Diskusi}

Pada tahap awal, setelah dilakukan mapping dan studi awal serta FGD dengan Pengurus Lembaga Tinggi Pesantren Luhur, kegiatan pertama pendampingan ini dilakukan melalui workshop entrepreneurship dengan tema "Penguatan Aspek Entreprenural Koperasi Pesantren Sebagai alternative Pengembangan Mahasantri Yang Mandiri Pada LTPLM Kelurahan Ketawanggede Kec Lowokwaru Kota Malang. Kegiatan ini diawali pretest yang berfungsi untuk menggali latar belakang dan potensi peserta dalam penguatan jiwa entrepreneurial dengan pertanyaan tematik sebagaimana berikut ini:

Pertama: Apa modal utama yang harus dimiliki oleh seseorang agar berdaya dalam mengembangkan bisnis atau usahanya. Hasil pretest menunjukkan bahwa mahasantri pada pertanyaan tersebut cukup homogen. Dari keseluruhan jawaban yang kami terima yaitu sekitar 60 jawaban, mayoritas menjawab modal utama seorang wirausaha adalah tekad dan niat. Sebagian besar lagi menjawab ke-istiqomaahan selain tekad dan niat. Jawaban lain yang juga cukup banyak antara lain jujur, tanggung jawab, pandai membaca peluang, strategi dan modal. Jawaban untuk pertanyaan pertama dengan tingkat kehomogenan yang tinggi menunjukkan kemampuan nalar peserta terkait modal utawa seorang wirausaha adalah sama. Semua jawaban yang disampaikan benar, hanya saja belum lengkap. Selanjutnya pertanyaan pertama ini disampaikan kembali pada post test.

Kedua, Pertanyaan apa saja yang menjadi tantangan bagi seorang wirausaha khususnya dimasa industry 4.0. Industri 4.0 merupakan otomatisasi dan pertukaran data dalam industri dengan menggunakan internet of things cloud dan artificial intelegence. Hasil pretest ini menunjukkan bahwa semua peserta sepakat menjawab bahwa tantangan utama pada industry 4.0 adalah adanya pesaing yang kuat. Selain itu, beberapa menjawab bahwa tantangan utama yan lain adalah kemampuan pengusaha dalam berinovasi produk. Hal yang perlu menjadi perhatian adalah tantangan ini bisa menjadi penyemangat bagi pelaku wirausaha untuk melakukan inovasi produk. 
Sehingga, sangat dimungkinkan jika kedua jawaban ini paling banyak dituliskan di lembar jawaban peserta

Ketiga, pertanyaan terkait tingkat pemahaman mahasantri terhadap koperasi dan pendapat mahasantri terhadap pentingnya koperasai dalam usaha mereka. Hasil pretest ini menunjukkan bahwa koperasi merupakan suatu usaha berbadan hukum yang tujuannya adalah untuk memberikan pinjaman kepada anggotanya. Sebagian lagi menjawab organisasi yang mewadai usaha para anggotanya. Dalam kebermanfaatan koperasi dalam meningkatkan usahanya, mahasantri mayoritas memilih menjawab untuk bergabung dengan koperasi. Meskipun demikian, ada beberapa mahasantri yang menjawab bahwa koperasi tidak akan membantu banyak terhadap usahanya.

Keempat, pertanyaan terkait peran koperasi dalam membantu kegiatan usaha dan kelemahan apa saja yang dapat diselesaikan jika bergabung dengan koperasi. Hasil pretest mahasantri mengacu kepada beberapa simpul, yakni koperasi dapat membantu mempromosikan serta menyalurkan barang kepada konsumen. Hal ini menjadi beralasan karena kendala bagi wirausahawan pada fase awal usahanya yakni pangsa pasar yang rendah. Sehingga dengan bergabung dengan koperasi diharapkan dapat mengenalkan produk ke masyarakat sehingga pangsa pasar menjadi luas.

Kelima, mengenai hal apa saja yang harus dimiliki wirausahawan ketika akan bergabung dengan koperasi. Adapun jawaban pada pertanyaan ini cukup beragam. Beberapa mahasantri mengatakan bahwa perlu adanya kepercayaan antar pihak. Selain itu, seorang wirausaha perlu mampu menciptakan ide yang kreatif sehingga dapat meyakinkan setiap pihak (khususnya koperasi) untuk bergabung dengan usahanya.

Dalam pendampingan melalui workshop ini, dijelaskan tentang koperasi dan kebermanfaatan koperasi dalam mendukung keberlanjutan usaha khususnya bagi pondok pesantren. Pemateri menjelaskan UU No. 25 tahun 1992 tentang Koperasi sebagai badan usaha yang beranggotakan orang-seorang atau badan hukum koperasi, dengan melandaskan kegiataannya berdasarkan prinsip koperasi sekaligus sebagai gerakan ekonomi rakyat yang berdasar atas azas kekeluargaan. ${ }^{7}$ Tujuan koperasi untuk kesejahteraan bersama dan didalam perkumpulan tersebut mengandung azas kekeluargaan yang saling bergotong royong dan tolong menolong diantara anggota koperasi.

Lebih lanjut, pemateri juga menjelaskan jenis usaha koperasi sesuai dengan kebutuhan anggotanya. Misalnya, koperasi serba usaha, koperasi simpan pinjam, koperasi manasuka dan lain-lain. Koperasi merupakan salah satu bagian penting dalam memajukan suatu usaha. Koperasi akan membantu pelaku usaha menghadapi ancaman dari luar seperti ketersediaan pasar juga membantu dari dalam seperti membantu ketersediaan modal dan bahan produksi.

7 Presiden Republik Indonesia, Undang-Undang Republik Indonesia Nomor 25 Tahun 1992 Tentang Perkoperasian (Indonesia, 1992). 
Setelah dilakukan pendampingan bagi mahasantri, maka tim pendamping melakukan post test untuk mengetahui dampak dan perubahan yang terjadi pada mahasantri terhadap Entrepreneural Koperasi Pesantren. Hasil pendampingan ini menunjukkan bahwa terdapat perubahan mindset dan pandangan santri terkait Entrepreneural Koperasi Pesantren. Hal ini terlihat dari beberapa indicator sebagai berikut.

Pertama, Terkait pandangan mahasantri terhadap modal utama seorang wirausaha, para peserta mahasantri telah mengalami perubahan yang semula mereka hanya berpendapat niat saja, namun setelah dilakukan pendampingan, mereka telah memiliki pandangan, bahwa modal tersebut tidak hanya niat, namun skill, jujur, tanggung jawab, dan kekuatan mental. Mahasantri juga telah memiliki pandangan, bahwa modal pembiayaan bukanlah menjadi hal utama pada pengembangan usaha, namun sikap-sikap yang bersifat softskill entrepreneur menjadi modal penting dalam pengembangan usaha koperasi pesantren. Mahasantri juga memahami bahwa akses modal pembiayaan bagi pengembangan koperasi pesantren cuku terbuka, karena pemerintah telah bekerjasama dengan pihak terkait sedang menggerakkan kegiatan pengembangan Usaha Kecil dan Menengah (UMKM).

Kedua, para mahasantri juga telah menyadari bahwa pemanfaatan internet dan artificial intelegence memberi kemudahan bagi bagi pengusaha baru. Karena kemudahan akses internet dalam kegiatan produksi, jasa pemasaran dan ketersediaan bahan produksi memudahkan pelaku usaha untuk memulai usahanya. Oleh karena itu, sangat penting sekali bagi mahasantri untuk terus mengembangkan kemampuan manajerial dalam menjalankan usahanya.

Ketiga, mahasantri juga telah memahami bahwa koperasi sangat penting dalam pengembangan usaha pesantren. Mereka memiliki pandangan bahwa kemampuan menciptakan ide yang kreatif adalah salah satu modal saja yang harus dimiliki seorang wirausaha. Modal lainnya adalah seorang wirausaha dengan segala kemampuannya harus mampu berkontribusi untuk mengembangkan koperasi. Hal ini menegaskan adanya sikap saling butuh akan menstimulasi setiap pihak untuk saling membantu dan pada akhirnya mencapai tujuan Bersama. Hal inilah yang menjadi dasar para wirausaha bergabung dengan koperasi.

Dari hasil pendampingan, ini mahasantri sepakat untuk terus mengembangkan koperasi pesantren dan diperlukan tindak lanjut terkait pendampingan manajemen wirausaha. Karena mereka telah menyadari bahwa peran koperasi tidak hanya membantu dari segi fisik saja. Koperasi juga dapat berkontribusi dari segi non fisik seperti edukasi. Dengan demikian, maka manajemen yang berkompeten agar dapat memberikan pelayanan yang prima baik dari segi fisik maupun non fisik.

Pemasaran sering diartikan sebagai proses penjualan atau kegiatan menjual. Padahal definisi pemasaran yang sesungguhnya adalah lebih luas dari sekedar kegiatan 
penjualan. Menurut Kotler, ${ }^{8}$ pemasaran merupakan proses social dan manajerial melalui penciptaan dan pertukaran timbal balik produk dan nilai dengan orang lain agar individu dan kelompok konsumen memperoleh apa yang mereka butuhkan dan mereka dapatkan.

Berdasarkan hasil penelusuran, ditemukan bahwa jiwa berwirausaha sudah Nampak pada diri mahasantri (objek pendampingan). Hal ini terwujud dalam upaya memasarkan produk yang dimiliki dengan mempertimbangkan kebutuhan santri lain. Suatu contoh yakni penjualan jajanan setelah proses kegiatan istighosah dan halaqah. Kegiatan istighosah dan halaqoh rutin dilaksanakan setelah jamaah sholat shubuh. Berdasarkan hasil penelusuran kegiatan ini memerlukan waktu yang tidak sebentar, setidaknya hingga pukul 06.30 WIB. Dengan jadwal yang sedemikian akan menjadi permasalahan bagi mahasantri yang ada jadwal kuliah pagi hari. Tentunya mereka tidak punya waktu banyak untuk sarapan. Dari keadaan itu muncul ide dari mahasantri untuk menjual kue basah setelah halaqoh dilakukan. Ide ini mendapatkan sambutan antusias dari para santri lain yang terwujud dalam habisnya kue yang dijajakan.

Selain penjualan kue setelah halaqoh, juga mulai muncul ide pengelolaan pemasaran untuk beberapa produk yang memang rutin diperlukan mahasantri. Seperti penjualan kitab kuning bagi mahasantri baru ataupun lama utamanya yang menjadi kajian wajib pada kegiatan pengajian Diniyah pada sore hari. Hal ini tentu membantu para santri, khususnya para santri baru. Dengan adanya penjualan kitab kuning yang dikelola oleh pesantren luhur, para santri tidak perlu sulit untuk mencari kebeberapa penjual peralatan mengaji.

Selain itu penyediaan kitab kuning, juga mulai dicetuskan pemasaran terintegrasi untuk pemenuhan pengenalan santri baru yang diadakan setiap tahun, seperti pengadaan jas almamater, block note dan sebagainya. Apalagi dengan seringnya diadakan kegiatan-kegiatan pengembangan skill mahasantri dengan mendatangkan narasumber-narasumber pilihan serta seringnya LTPLM mengadakan even-even serta perlombaan ditingkat se Malang Raya atau se Jawa timur.

Contoh lain yakni dengan penjualan merchandise dan kaos. Aktivitas ini bertepatan dengan diadakannya Harlah dan Haul Al Maghfurullah Prof. Dr. KH Ahmad Mudlor SH yang ke IV yang diadakan mulai tanggal akhir September sampai puncak acara pada tanggal 6 Oktober 2019. Untuk memeriahkan kegiatan tersebut, para santri pesantren luhur tercetus ide penguatan branding iconic LTPLM dengan membuat dan menjual mercandhice seperti gantungan kunci, stiker serta totebag dengan tulisan atau logo LTPLM. Produk lain yakni dengan membuat kaos yang bertuliskan LTPLM. Branding merupakan kegiatan komunikasi yang dilakukan oleh organisasi dengan tujuan untuk membangun dan membesarkan sebuah brand atau merek.

Gagasan semacam ini bersifat berkelanjutan dan jangka panjang. Artinya, selalu

8 Philip Kotler and Keller, Marketing Management (Prentice Hall: Pearson Education, 2012). 
muncul gagasan-gagasan berwirausaha pada diri mahasantri dengan mempertimbangkan berbagai macam peluang, meskipun beberapa mahasantri telah lulus dan keluar dari pesantren ini. Hal ini tidak terlepas dari kemampuan para mahasantri untuk melihat peluang yang ada. Lebih jauh, lingkungan yang memberikan contoh perilaku wirausaha pada akhirnya akan menularkan kepada mahasantrimahasantri yang lain untuk melakukan kegiatan yang serupa.

Meskipun begitu, dari hasil penelusuran ditemukan indikasi bahwa gagasan dan kegiatan berwirausaha berjalan secara terpisah. Selain itu, kegiatan berwirausaha belum memberikan kontribusi yang maksimal pada pesantren luhur tersebut. Hal ini berarti koperasi pada pesantren ini belum menaungi semua kegiatan berwirausaha para maha santri. Jika peran koperasi pesantren dapat dimaksimalkan, maka bukan tidak mungkin mahasantri yang menjalankan kegiatan wirausaha tersebut menjadi anggota koperasi pesantren luhur.

Disisi yang lain, dengan aktifnya koperasi pesantren akan memberikan peluang untuk memajukan pesantren tersebut. Dengan banyaknya anggota akan mendorong berkembangnya koperasi. Salah satu manfaat berkembangnya koperasi pesantren adalah mampu menyediakan kebutuhan anggotanya dengan biaya yang terjangkau. Sehingga hal ini akan menjadi daya tarik tersendiri bagi sebuah pesantren dalam menjaring calon santri yang baru. Disamping itu, gagasan berwirausaha yang selalu muncul dari mahasantri memungkinkan koperasi pesantren ini untuk terus berkembang dalam jangka panjang.

Pengabdian ini juga berupaya menelusuri sejauh mana pemahaman para mahasantri terkait urgensi dari menjadi entrepreneur dan anggota koperasi pesantren. Hasil dari penelusuran tersebut dapat dirangkum dalam Tabel 1.

Tabel 1. Pemahaman menjadi entrepreneur dan anggota koperasi pesantren

\begin{tabular}{llc}
\hline No & \multicolumn{1}{c}{ Pernyataan } & $\begin{array}{c}\text { Nilai rata- } \\
\text { rata }\end{array}$ \\
\hline $\mathbf{1}$ & Saya memahami pentingnya menjadi entrepreneur & 3,50 \\
\hline $\mathbf{2}$ & Saya menjadi lebih mandiri setelah berbisnis (ber-entrepreneur) & 3,28 \\
\hline $\mathbf{3}$ & $\begin{array}{l}\text { Saya membutuhkan suatu lembaga yang dapat membantu saya } \\
\text { meningktakan bisnis saya }\end{array}$ & 3,40 \\
\hline $\mathbf{4}$ & Saya memahami pentingnya Koperasi & 3,10 \\
\hline $\mathbf{5}$ & Saya memiliki keinginan untuk bergabung dengan Koperasi & 3,13 \\
\hline $\mathbf{6}$ & $\begin{array}{l}\text { Bisnis Saya dapat berkembang dengan baik jika bergabung dengan } \\
\text { Koperasi }\end{array}$ & 3,10 \\
\hline $\mathbf{7}$ & $\begin{array}{l}\text { Pelatihan ini bermanfaat bagi Saya untuk mengetahui tentang } \\
\end{array}$ & Koperasi \\
\hline
\end{tabular}

Berdasarkan data tersebut dapat diketahui bahwa rata-rata nilai tersebut sebesar 3,29. Nilai ini termasuk dalam kategori setuju. Artinya adalah para mahasantri 
memahami pentingnya menjadi entrepreneur dan menjadi anggota koperasi. Berdasarkan tabel di atas, nilai tertinggi didapatkan oleh poin nomer 7 yakni pelatihan ini bermanfaat bagi saya untuk mengetahui tentang koperasi. Hal ini menunjukkan bahwa pentingnya kegiatan pengabdian ini. Pengabdian ini memberikan kontribusi yang positif terhadap pengetahuan mahasantri terkait dengan Koperasi Pesantren

Selanjutnya nilai terendah dimiliki item nomer 4 dan 7 dengan nilai 3,10. Nilai ini mengindikasikan bahwa para mahasantri menyetujui adanya koperasi dan ingin bergabung menjadi anggota koperasi pesantren. Jika ditelusuri lebih dalam, temuan pada poin no 1 yang memiliki nilai sebesar 3,50 menunjukkan bahwa memang gagasan konsep wirausaha pada pesantren luhur malang ini muncul secara terus menerus dari mahasantri. Hal ini dikarenakan mereka meyakini menjadi entrepreneur merupakan sesuatu yang tidak bisa hanya dilihat sebelah mata saja.

Hasil pendampingan di atas selaras dengan kajian Gunawan Aji yang mengungkapkan bahwa pengembangan koperasi pesantren masih banyak ditemukan persoalan, diantaranya terkait dengan partisipasi dan kinerja koperasi pesantren, serta kualitas sumber daya manusia dalam mengelola koperasi pesantren. Oleh karena itu, maka komitmen, dan kemampuan untuk terus mengembangkan anggota koperasi agar tetap inovatif mutlak diperlukan oleh management koperasi pesantren. ${ }^{9}$ Hasil kajian Syarbani juga menandaskan bahwa rendahnya kinerja koperasi santri sangat dipengaruhi oleh kurangnya partisipasi, komitmen dan kemampuan untuk berinovasi pondok pesantren..$^{10}$

\section{Kesimpulan}

Berdasarkan pemaparan hasil diatas diketahui bahwa kegiatan pemasaran atau penjualan produk dilakukan secara mandiri oleh para santri. Fenomena tersebut merupakan modal awal untuk keberlanjutan dan keberlangsungan entrepreneurial. Keberadaan koperasi pesantren yang mampu menaungi berbagai kegiatan wirausaha para santri akan memberikan dampak positif pada perkembangan pesantren. Keberadaan koperasi pada pesantren pada akhirnya memiliki potensi untuk terus berkembang dalam jangka panjang. Dalam pendampingan ini telah memberikan perubahan baik cara pandang maupun sikap mahasantri terkait peningkatan kualitas sumberdaya manusia mahasantri yang handal dalam mengelola koperasi pesantren. Hal ini tercermin dari beberapa kegiatan usaha yang mampu memberikan dampak positif kepada pesantren seperti penjualan kitab kuning, merchandise dan kaos. Jika ditinjau dari sisi yang lain, Terbentuknya kreatifitas mahasantri dalam menambahkan ide-ide baru guna meningkatkan nilai ekonomi dan menciptakan lingkungan pesantren dinamis

${ }^{9}$ Aji, “Faktor-Faktor Yang Mempengaruhi Kinerja Koperasi Pondok Pesantren."

10 Syarbani, "Analisis Pengaruh Partisipasi Santri Komitmen Dan Kemampuan Berinovasi Terhadap Kinerja Koperasi Pondok Pesantren Di Kota Semarang." 
dan kreatif dapat dilihat dari berbagai macam ide penguatan dan pengembangan.

\section{Daftar Referensi}

Aji, Gunawan. "Faktor-Faktor Yang Mempengaruhi Kinerja Koperasi Pondok Pesantren." Walisongo: Jurnal Penelitian Sosial Keagamaan 19, no. 1 (2011): 231-260.

Bakri, Masykuri. Pemberdayaan Masyarakat Pendekatan RRA Dan PRA. Surabaya: Visipress Media, 2010.

Hasyim. Analisis Peranan Partisipasi Santri Terhadap Perkembangan Koperasi Pondok Pesantren Di Kota Semarang. Semarang, 2008.

Kotler, Philip, and Keller. Marketing Management. Prentice Hall: Pearson Education, 2012.

Ma'sum, Toha, and Muh Barid Nizarudin Wajdi. "Pengembangan Kemandirian Pesantren Melalui Program Santripreneur.” ENGAGEMENT 2, no. 2 (2018): 221-232.

Maryati, Wiwik. "Peran Perguruan Tinggi Dalam Pemberdayaan Entrepreneurship Untuk Mengembangkan Wirausahawan Kecil Menghadapi Persaingan Global." Prosiding Seminas 1, no. 2 (2012).

Noer, Deliar. Perubahan, Pembaruan, Dan Kesadaran Menghadapi Abad Ke-21. Dian Rakyat, 1988.

Presiden Republik Indonesia. UNDANG-UNDANG REPUBLIK INDONESIA NOMOR 25 TAHUN 1992 TENTANG PERKOPERASIAN. Indonesia, 1992.

Syarbani, Hasyim. "Analisis Pengaruh Partisipasi Santri Komitmen Dan Kemampuan Berinovasi Terhadap Kinerja Koperasi Pondok Pesantren Di Kota Semarang." Economica: Jurnal Ekonomi Islam 2, no. 2 (2012): 27-42. 